\title{
DAMPAK HUKUMAN FISIK TERHADAP PERILAKU DELINKUEN REMAJA
}

\author{
Nelly Marhayati \\ Institut Agama Islam Negeri Bengkulu \\ Jl. Raden Fatah, Pagar Dewa Bengkulu \\ Email: stainbengkulu@stainbengkulu.ac.id
}

\begin{abstract}
Abstrak:
Tulisan ini bertujuan untuk mengetahui dampak pemberian hukuman fisik terhadap perkembangan perilaku delinkuen remaja. Remaja berada pada tahapan pencarian jati diri dalam prakteknya banyak mengalami guncangan, seperti tawuran, narkoba, perbuatan kriminal, sex bebas dan lain sebagainya. Dalam hal terjadinya penyimpangan perilaku, perilaku delinkuen juga sangat mungkin terjadi pada periode perkembangan remaja. Perilaku delinkuen ini diartikan sebagai perilaku anak yang nakal bahkan cenderung kepada melanggar hukum. Banyak penyebab terjadinya perilaku delinkuen ini. Berdasarkan beberapa sumber yang penulis paparkan ternyata pemberian hukuman fisik pada anak di sekolah bukan faktor utama perilaku delinkuen remaja. Namun, dalam tulisan ini belum dibahas secara medetail bagaimana jika hukuman fisik tersebut diterima anak dari pola asuh orangtua. Artinya hukuman fisik didapatkan anak dari orangtuanya di rumah.
\end{abstract}

\begin{abstract}
:
This paper aims at finding out whether there is the effect of corporal punishment toward delinquency adolescent behavioral development or not. Adolescent who struggle with sense of identity experienced many shocks for instance involving in brawl, drugs, crime, free sex and so forth. In relation to the case, the delinquency behavior occur likely in the period of adolescent development. The delinquency behavior is interpreted as a naughty child behavior even it inclined to break the law. There are many of causes of this delinquency behavior. According to some sources that the authors describe, it shows that physical punishment of children in schools is not a major factor of delinquency adolescent behavior. However, in this paper, it has not been discussed in detail if the physical punishment of children received parental upbringing. This means that the physical punishment of children got from their parents at home.
\end{abstract}

\section{Kata Kunci:}

Perilaku delinkuen, hukuman fisik, perkembangan remaja

RUANG lingkup pembahasan mengenai masalah pendidikan sangat luas tidak hanya sebatas rumitnya penyelenggaraan UN, kurikulum, strategi belajar mengajar dan lain sebagainya. Salah satu pembahasan yang menarik untuk dibahas adalah tentang pemberian reward (hadiah) dan punishment (hukuman). Sudah sama-sama dipahami bahwa pemberian reward diharapkan akan membuat seseorang mengulang perilakunya sedangkan pemberian punishment diharapkan akan membuat seseorang menghentikan perilakunya. Pemberian hadiah dan hukuman dianggap efektif bagi munculnya perubahan perilaku individu sesuai dengan yang diharapkan. Pemberian re- 
ward dan punishment tidak hanya diterapkan di lingkungan pendidikan, namun juga di lingkungan kerja bahkan bisa diterapkan pada diri pribadi. Sebagai salah satu sarana motivasi diri.

Pemberian reinforcement atau penguatan apabila dilakukan dengan cara dan prinsip yang tepat dapat mengefektifkan pencapaian tujuan penggunaannya. Beberapa tujuan dari penguatan antara lain:

- Meningkatkan perhatian siswa dalam proses belajar

- Membangkitkan, memelihara, dan meningkatkan motivasi belajar siswa

- Mengarahkan pengembangan berfikir siswa ke arah berfikir divergen

- Mengatur dan mengembangkan diri anak sendiri dalam proses belajar

- Mengendalikan serta memodifikasi tingkah laku siswa yang kurang positif serta mendorong munculnya tingkah laku yang produktif. ${ }^{1}$

Penguat sebenarnya tidak hanya mengandung arti sebagai hadiah saja melainkan penguat bisa juga diartikan sebagai hukuman. Pemberian reward dan punishment adalah merupakan bagian dari reinforcement atau penguat dari suatu perilaku. Reinforcement positif disebut juga dengan reward sedangkan reinforcement negative adalah punishment. Reinforcement sangat erat hubungannya dengan motivasi. Siswa yang telah di reinforced atau diperkuat untuk belajar (contohnya dengan memberikan nilai yang bagus dan pujian dari orangtua dan gurunya) akan "termotivasi" untuk belajar. Tetapi siswa yang tidak diperkuat untuk belajar karena mereka telah belajar tetapi tidak mendapatkan nilai bagus atau karena orangtua atau guru tidak memujinya tidak akan "termotivasi" untuk belajar. Demikian juga siswa yang telah "dihukum" dalam belajar, misalnya, ditertawakan oleh siswa-siswa lain, kemungkinan tidak akan "termotivasi" untuk belajar. ${ }^{2}$

Pemberian penguat positif berupa hadiah sudah sangat jelas pengaruhnya kepada anak. Sedangkan pemberian penguat negative berupa hukuman masih menarik untuk dibahas terutama pemberian hukuman fisik. Ternyata dalam prakteknya masih sering terjadi pemberian hukuman secara fisik kepada peserta didik, yang berakibat tidak langsung tetapi muncul beberapa tahun kemudian dalam masa perkembangan anak selanjutnya.

\section{PEMBAHASAN}

\section{Hukuman Fisik}

Allah SWT berfirman dalam surah At-Taghabun ayat 14, yang artinya:

"Hai orang-orang yang beriman, sesungguhnya di antara isteri-isterimu dan anak-anakmu ada yang menjadi musuh bagimu, maka hati-hatilah kamu terhadap mereka. Dan jika kamu memaafkan mereka, tidak memarahi serta mengampuni mereka, maka sesungguhnya Allah Maha Pengampun lagi Maha Penyayang".

Menghukum anak yang sudah baligh, baik laki-laki ataupun perempuan memang disyariatkan oleh Islam. Terutama ketika anak tidak melakukan kewajiban ber- 
ibadah seperti sholat. Hal ini sudah dijelaskan dalam sebuah hadis Rasulullah SAW, bahwa anak-anak yang sudah baligh apabila diperintahkan sallat tetapi mereka tidak melakukannya maka anak tersebut boleh dihukum bahkan orang tua boleh memukulnya.

Hukuman adalah suatu perbuatan, dimana secara sadar dan sengaja menjatuhkan nestapa atau kesedihan kepada orang lain, baik dari segi kejasmanian maupun dari segi kerohanian orang lain dimana orang tersebut mempunyai kelemahan dibanding diri kita sehingga kita mempunyai tanggung jawab untuk membimbing dan melindunginya. Tujuan hukuman bagi anak didik adalah:

1. Hukuman diberikan karena adanya pelanggaran

2. Hukuman diberikan dengan tujuan agar tidak terjadi pelanggaran. ${ }^{3}$

Hukuman pantas dilakukan jika ada nilai positif dan pedagogisnya. Dalam dunia kependidikan hukuman merupakan hal yang wajar dilakukan, apabila hukuman yang diberikan menimbulkan sumbangan yang berarti bagi perkembangan siswa. Hukuman fisik atau badan adalah salah satu jenis hukuman, hukuman ini memberi akibat yang merugikan anak, bahkan dapat menimbulkan gangguan kesehatan bagi anak didik. Misalnya anak didik ketahuan merokok oleh gurunya, kemudian oleh guru anak dihukum untuk merokok terus menerus selama waktu sekolah, hal ini tentunya bisa berakibat anak batuk, pusing bahkan sakit. ${ }^{4}$

Hukuman fisik atau badan atau dalam bahasa Inggris disebut dengan corporal punishment's oleh Straus dianggap sebagai alat yang digunakan untuk mengontrol dan memperbaiki perilaku anak. Namun, lebih jauh Straus menyatakan bahwa beberapa penelitian menunjukkan bahwa penggunaan kekerasaan untuk mendisiplinkan anak dapat membuat anak berfikir bahwa perilaku agresi dan delinkuen boleh dilakukan untuk mencapai tujuan mereka sehingga semakin diberi hukuman fisik dan bukannya memperbaiki perilaku mereka menjadi lebih baik tetapi menjadi semakin anti sosial. ${ }^{5}$ Sampai saat ini masih banyak perdebatan di antara para ahli tentang pemberian hukuman fisik apakah memang mampu mendisiplinkan anak atau malah menimbulkan penyimpangan perilaku berupa perilaku agresif dan perilaku delinkuen.

Sedikit sekali bukti yang menunjukkan bahwa pemberian hukuman efektif bagi manusia. Justru banyak laporan tentang pemberian hukuman fisik atau badan menunjukan kegagalan seorang guru. Hukuman badan merupakan penyaluran frustasi guru yang terpendam dan meminta anak untuk melakukan latihan olah raga di lapangan sekolah adalah salah satu alternative yang lebih baik. ${ }^{6}$ Selain pemberian hukuman fisik, hukuman lain yang sangat tidak dapat dipertanggung jawabkan adalah usaha untuk menghubungkan tambahan tugas dengan perilaku buruk anak. Misalnya meminta anak untuk menulis "saya tidak akan....." sebanyak lima puluh atau seratus kali tidak mempunyai arti apapun. Tugas sekolah seharusnya diberikan kepada anak dalam kondisi yang positif bukannya diperlakukan sebagai suatu hukuman. ${ }^{7}$

Menurut J. Drost, tindakan yang perlu dihukum adalah tindakan asosial. Tindakan yang merugikan sesama, merugikan orang tua, keluarga, teman-teman sekolah 
dan juga sekolah itu sendiri. Jika di satu kelas anak-anak yang tidak ada gurunya terdengar ramai, sementara di kelas sebelah kiri dan kanannya sedang belajar. Maka tindakan anak-anak tersebut di anggap asosial sehingga wajar jika diberikan hukuman. ${ }^{8}$ Berdasarkan pendapat tersebut, pemberian hukuman boleh saja dilakukan apabila memang terbukti anak atau siswa melanggar peraturan sekolah dan mengganggu ketertiban sekolah atau berakibat kepada terganggunya kepentingan pihak-pihak lain maka anak atau siswa tersebut boleh dihukum.

Pemberian hukuman terhadap siswa menurut J. Drost tidak boleh berupa hukuman fisik. Hukuman yang boleh diberikan hanyalah berupa hukuman yang ada hubungannya dengan tugas pembelajaran. Dalam pemberian hukuman juga harus diperhatikan oleh guru untuk tidak terlalu cepat memberikan hukuman terhadap kesalahan yang telah dilakukan siswa. Sebelum hukuman diberikan siswa harus diberi penjelasan terlebih dahulu kenapa dia dihukum. Jika hal itu dilakukan maka akan membuat anak menjadi penakut, tidak berani berinisiatif hanya bertindak jika ada komando. Jika anak terus-terusan melakukan kesalahan setelah dilakukan bimbingan dan pembinaan maka perlu ada tindakan tegas. ${ }^{9}$

Pemberian hukuman yang awalnya bertujuan untuk memperlemah tingkah laku hendaknya diterapkan secara bijaksana di kelas. Hukuman pada dasarnya tidak akan menghilangkan tingkah laku seperti yang dijelaskan dalam operant conditioning. Hukuman di sekolah dianggap sia-sia dan tidak edukatif, hukuman tidak dapat membuat lebih baik dengan cara yang lebih manusiawi. Lebih baik hukuman dihapuskan dan digantikan dengan mengajarkan bagaimana bersikap etis yang baik dalam setiap tindakan yang benar. ${ }^{10}$

Tujuan pemberian hukuman pada anak menurut Arini el Ghaniy adalah sebagai berikut:

\section{Agar anak tidak mengulang kejadian yang sama}

Terulangnya suatu kesalahan yang dilakukan oleh seorang anak kemungkinan adalah akibat kurang tanggapnya anak, kurang memperhatikan, menganggap sesuatu itu adalah hal yang biasa, ketika ada temannya yang juga melakukan hal yang sama atau ada faktor lain yang menjadikan anak lupa dan mengabaikan peringatan. Sehingga perlu adanya kesepakatan tertentu terhadap anak mengenai hukuman apa yang harus diberikan apabila perbuatan yang melanggar tersebut kembali dilakukan.

\section{Bisa mengambil pelajaran dan hikmah}

Pemberian hukuman diharapkan dapat mengajarkan kepada anak tentang akibat dari perbuatan yang ia lakukan. Sehingga ke depannya anak akan lebih berhatihati untuk tidak mengulangi kesalahan yang sama. Lebih baik lagi apabila anak mampu mensosialisasikan perbuatan buruknya dan apa akibat yang akan didapat dengan perbuatan tersebut kepada teman, saudara atau orang lain. Artinya anak benarbenar sudah dapat mengambil pelajaran terhadap hukuman yang telah dia dapatkan. 


\section{Konsistensi sebuah perjanjian}

Hukuman yang baik adalah merupakan hasil dari konsensus atau perjanjian antara anak dan orang tua. Bagi anak, jika memang ia berbuat salah harus menyadari sendiri bahwa ia harus dihukum sesuai dengan perjanjian awal. Sedangkan bagi orangtua juga harus konsisten dengan hukuman yang akan diberikan. Jangan hanya diucapkan di mulut, tetapi dibuktikan anak dihukum ketika melakukan kesalahan. ${ }^{11}$

Lebih jauh mengenai pemberian hukuman terutama hukuman fisik Koesworo menyatakan bahwa menurut Bandura dan Walters ketidakefektifan beberapa bentuk hukuman dalam pengendalian agresi yakni bahwa individu yang delinquent dan agresif sebagian besar berasal dari keluarga dengan orang tua yang menggunakan hukuman fisik secara berlebihan di dalam menegakan kedisiplinan pada ana-anak. ${ }^{12}$

Berdasarkan beberapa pendapat di atas dapat dikatakan bahwa pemberian hukuman fisik pada anak akan lebih berpengaruh terhadap perilaku anak adalah jika anak mengalami perlakuan tersebut di rumah yang berasal dari orangtuanya sendiri. Sedangkan hukuman fisik yang diterima dari sekolah juga tidak akan efektik jika tujuannya untuk menghentikan perilaku menyimpang siswa.

\section{Perkembangan Remaja}

Sering muncul kerancuan di dalam memahami arti perkembangan dengan pertumbuhan padahal kedua hal ini sangat berbeda namun tetap saling berpengaruh. Pertumbuhan berkaitan dengan kuantitatif yang menyangkut peningkatan ukuran dan struktur biologis. Pertumbuhan adalah perubahan secara fisiologis yang berlangsung secara normal pada anak yang sehat, dalam perjalanan waktu tertentu. Hasil pertumbuhan antara lain berwujud bertambahnya ukuran kuantitatif badan anak, seperti panjang, berat, dan kekuatannya. Dengan singkat dapat dikatakan bahwa pertumbuhan lebih mengacu kepada proses perubahan dan pematangan fisik. ${ }^{13}$

Sedangkan perkembangan menurut Bijou dan Baer adalah perubahan progresif yang menunjukkan cara organism bertingkah laku dan berinteraksi dengan lingkungan. Interaksi yang dimaksud di sini adalah apakah suatu jawaban tingkah laku akan diperlihatkan atau tidak, tergantung dari perangsang-perangsang yang ada di lingkungannya. Rumusan lain mengenai perkembangan dikemukakan oleh Libert, Paulus dan Strauss yaitu perkembangan adalah proses perubahan dalam pertumbuhan pada suatu waktu sebagai fungsi kematangan dan interaksi dengan lingkungan. Istilah perkembangan lebih mencerminkan sifat-sifat yang khas mengenai gejala-gejala psikologis yang tampak. Perkembangan dapat juga digambarkan sebagai suatu proses yang kekal dan tetap yang menuju ke arah suatu organisasi pada tingkat integrasi yang lebih tinggi, berdasarkan proses pertumbuhan, kematangan dan belajar. ${ }^{14}$

Dapat penulis simpulkan di sini pertumbuhan lebih kepada perkembangan fisik sedangkan perkembangan mengacu kepada perkembangan psikis individu. Pertumbuhan bersifat kuantitatif, berubah, bertumbuh dan berkembang. Sedangkan perkembangan bersifat kualitatif, tetap, tidak akan terulang kembali dan menuju kepada suatu kesempurnaan. Perkembangan dan pertumbuhan saling mempengaruhi, jika per- 
kembangan seseorang mengalami hambatan maka partumbuhan orang tersebut akan mengalami hambatan demikian pula sebaliknya. Dapat penulis contohkan disini seseorang yang terlahir dengan pertumbuhan fisik yang tidak sempurna biasanya akan berpengaruh terhadap perkembangan psikisnya, dimana orang tersebut akan mengalami hambatan pada perkembangan sosial emosinya.

Mengenai pentahapan perkembangan pribadi manusia dari sudut tinjauan umum penyelenggaraan pendidikan meliputi 5 tahapan perkembangan yaitu:

1. Tahap enam tahun pertama; tahap perkembangan fungsi penginderaan yang memungkinkan anak mulai mampu untuk mengenal lingkungannya.

2. Tahap enam tahun kedua; tahap perkembangan fungsi ingatan dan imajinasi individu yang memungkinkan anak mulai mampu menggunakan fungsi intelektual dalam usaha mengenal dan menganalisis lingkungannya.

3. Tahap enam tahun ketiga; tahap perkembangan fungsi intelektual yang memungkinkan anak mulai mampu mengevalusi sifat-sifat serta menemukan hubunganhubungan antarvariabel di dalam lingkungannya.

4. Tahap enam tahun keempat; tahap perkembangan fungsi kemampuan berdikari, "self direction" dan "self controle".

5. Tahap kematangan pribadi; tahap dimana intelek memimpin perkembangan semua aspek kepribadian menuju kematangan pribadi di mana manusia berkemampuan mengasihi Allah dan sesama manusia. ${ }^{15}$

Kelima tahapan perkembangan di atas dapat dijadikan sebagai salah satu acuan untuk melakukan tindakan selanjutnya dalam memahami karakter perkembangan siswa. Tentang proses perkembangan terutama pada remaja penulis mencoba menambahkan faktor-faktor lain yang hendaknya diperhatikan yaitu meliputi perkembangan intelektual, sosial, bahasa dan emosional. Perkembangan keempat aspek ini perlu diperhatikan untuk terciptanya proses belajar mengajar yang efektif dan efisien.

Perkembangan intelektual dan bahasa yang termasuk kedalam ranah kognitif sangat dipengaruhi oleh faktor lingkungan dan bawaan anak itu sendiri. Namun tidak dapat dipungkiri bahwa faktor bawaan sangat besar mempengaruhi perkembangan intelektual dan kemampuan berbahasa anak. Fenomena di lapangan menunjukkan bahwa banyak orangtua yang merasa kecewa dan frustasi terhadap anakanaknya akibat pretasi belajar mereka yang rendah, sementara semua stimulus untuk meningkatkan intelektual daya berfikir anak sudah diberikan. Hal ini membuktikan bahwa faktor genetik tetap menjadi yang utama dalam perkembangan kognitif anak. Oleh karena itu, fokus orangtua hendaknya bukan hanya kepada prestasi belajar anak di sekolah tetapi lebih kepada pencarian kecerdasan-kecerdasan lain pada diri anak karena jika merujuk pada pendapat Howard Gardner terdapat 8 kecerdasan pada setiap diri inidvidu yang bisa di explore dalam rangka untuk meningkatkan kualitas kehidupan individu tersebut.

Perkembangan sosial dan emosional sangat dipengaruhi oleh lingkungan dan pola asuh seseorang atau dalam hal ini siswa. Pengaruh pola asuh dan lingkungan terhadap perkembangan sosial dan emosi anak dimulai sejak bayi, bahkan beberapa 
ahli berpendapat bahwa ketika bayi di dalam kandungan pun apa yang dialami dan dirasakan oleh ibu akan mempengaruhi perkembangan emosi anak nantinya. Menurut Bridges emosi anak akan berkembang melalui pengalaman, sekalipun masih dangkal dan berubah-ubah. Ketika emosi marah dan takut pada bayi ditunjukkan dengan menangis atau gemetar, usia 8 bulan mulai bisa membedakan perasaan marah dan takut. Selanjutnya perubahan ekspresi emosi semakin lama akan semakin jelas dan berbeda. Contohnya, ketika bayi marah maka akan menyerang semua benda di sekitarnya sebagai ekspresi dari rasa marahnya, namun perlahan ia mampu memusatkan ekspresi emosinya langsung kepada objek yang memang menimbulkan kemarahan. ${ }^{16}$

Perkembangan sosial akan menekankan perhatiannya kepada pertumbuhan yang bersifat progresif. Seorang anak yang lebih besar tidak bersifat statis dalam pergaulannya, karena dirangsang oleh lingkungan sosial, adat istiadat, kebiasaan-kebiasaan kelompok dan minat serta keinginannya. Tingkah laku batiniah dan lahiriah akan berubah seiring dengan perubahan lingkungannya. Tidak seorangpun akan bersifat pasif terhadap pengaruh dari pergaulan sehingga perkembangan sosial seseorang akan sangat dipengaruhi oleh situasi lingkungan untuk mencapai kedewasaan. ${ }^{17}$

Obsesi pertama bagi seorang remaja adalah bisa membebaskan diri dari dominasi keluarga terutama ayah yang seringkali mencampuri urusan-urusan pribadi anaknya. Terkadang ayah terkesan memposisikan dirinya seperti seorang polisi yang selalu ingin tahu apa yang dilakukan oleh anaknya.

Tugas perkembangan memegang peranan yang penting untuk menentukan arah perkembangan yang normal. Begitu juga halnya pada remaja. ${ }^{18}$ Semua tugas perkembangan pada remaja menuntut perubahan yang besar dalam sikap dan pola perilaku anak sebagai persiapan untuk menghadapi masa dewasa. ${ }^{19}$

Tugas perkembangan pada masa remaja yang disertai dengan berkembangnya kapasitas intelektual, stress dan harapan-harapan baru yang dialami remaja membuat remaja mudah mengalami gangguan baik berupa gangguan pikiran, perasaan maupun gangguan perilaku. Stress, kesedihan, kecemasan, kesepian, keraguan pada diri remaja membuat remaja mengambil resiko dengan melakukan kenakalan. ${ }^{20}$

Mengingat pentingnya tugas-tugas perkembangan pada perkembangan periode remaja, mendesak orangtua untuk membuat suatu strategi di dalam pemenuhan tugas-tugas perkembangan tersebut. Strategi yang bagus dan cocok untuk remaja adalah strategi menghormati kecenderungannya untuk bebas, merdeka tanpa mengabaikan perhatian padanya. Dari satu sisi strategi ini dapat menciptakan iklim kepercayaan antara ayah dan anak, dari sisi lain dapat meletakan garis perencanaan yang jelas ke arah adaptasi yang sehat. Dimana tentunya akan sangat membantu perkembangan, kematangan dan keseimbangan jiwa remaja. ${ }^{21}$

Membangun hubungan yang baik antara anak dan orang tua hendaknya dilakukan sejak anak berusia dini. Sejak kecil anak sudah harus diberi pemahaman bahwa hanya orangtua tempat mereka mencurahkan semua isi hati, bertanya dan berce- 
rita tentang apapun yang mereka alami dan mereka ingin ketahui. Jika hal ini dilakukan sejak kecil maka ketika anak menginjak remaja, anak sudah menjadi terbiasa untuk dekat dengan orangtua dan selalu ingin kembali ke orang tua ketika ingin bertanya, ingin mengetahui sesuatu bukannya mencari informsi dengan teman atau orang-orang lain yang tidak bisa dipertanggungjawabkan perkataannya.

\section{Perilaku Delinkuen Remaja}

Perubahan kepribadian biasanya berimbas kepada berubahnya perilaku seseorang. Perubahan ini tidak terjadi secara spontan, tetapi merupakan hasil pematangan, pengalaman, tekanan dari lingkungan sosial, budaya dan faktor-faktor dari indivi$\mathrm{du}$ itu sendiri. Pola asuh dan pola didikan juga dapat mengakibatkan terjadinya perubahan kepribadian pada remaja. Seorang anak yang pada awalnya dinilai oleh orangtuanya sebagai seorang anak yang baik, penurut dan tidak pernah membangkang bisa saja berubah sebaliknya ketika dia menginjak usia remaja.

Bisa juga dikatakan bahwa lajunya proses perkembangan perilaku dan pribadi serta terjadinya perubahan kepribadian pada remaja dipengaruhi oleh tiga faktor dominan yaitu bawaan (heredity), kematangan (maturation), dan lingkungan (environment) termasuk belajar dan latihan (training and learning). Ketiga faktor tersebut senantiasa bervariasi dalam hal pengaruhnya mungkin dapat menguntungkan atau menghambat atau membatasi lajunya proses perkembangan itu sendiri. ${ }^{22}$

Masa remaja adalah masa pencarian identitas diri. Pada periode ini masyarakat memandang bahwa remaja lebih banyak yang bermasalah dari pada yang tidak bermasalah. Pandangan masyarakat ini adalah karena berdasarkan penilaian mereka terhadap tingkah laku remaja yang sering kali tidak bisa diterima oleh lingkungan dimana remaja tersebut tinggal.

Lebih jauh mengenai beberapa kategori masalah yang muncul pada masa remaja adalah sebagai berikut:

\section{Masalah-masalah yang timbul akibat perkembangan fisik dan psikomotor}

1. Adanya variasi yang mencolok dalam tempo dan irama perkembangan fisik baik individual maupun kelompok antara remaja laki-laki dan perempuan. Wanita lebih cepat sekitar 1-2 tahun. Hal ini dapat menimbulkan kecanggungan-kecanggungan dalam bergaul antara satu dengan yang lain.

2. Perkembangan ukuran tinggi dan berat badan yang kurang proporsional akan dapat menimbulkan efek psikologis tersendiri, dimana akan muncul nama-nama cemoohan seperti si gendut, si kurus dan sebagainya. Hal ini akan membawa ke arah self-rejection karena body image-nya tidak sesuai dengan self-picture yang diharapkan.

3. Perubahan suara dan peristiwa menstruasi dapat juga menimbulkan gejala-gejala tertentu seperti munculnya perasaan malu.

4. Matangnya organ reproduksi, membutuhkan pemuasan biologis. Dimana jika tidak dibimbing dengan norma-norma tertentu akan membawa remaja melakukan perilaku-perilaku yang menyimpang dari norma kesusilaan. 


\section{Masalah-masalah yang timbul berhubungan dengan perkembangan bahasa dan pe- rilaku kognitif}

1. Bagi beberapa individu mempelajari bahasa asing adalah mengasyikan tetapi bagi sebagian yang lain mempelajari bahasa asing adalah siksaan. Hal ini dikarenakan adanya kelemahan dalam hal fonetik. Dimana kelemahan-kelemahan ini juga bisa dijadikan semacam cemoohan, yang juga akan memunculkan perilaku negatif seperti siswa akan membenci gurunya dan pelajaran bahasa asing itu sendiri.

2. Intelegensi juga mempengaruhi kapasitas belajar bagi yang IQ nya tinggi (superior) atau di bawah rata-rata (slow learners). Jika tidak dibimbing secara memadai maka perbedaan ini akan menimbulkan akibat-akibat psikologis. Misalnya perasaan rendah diri karena tidak pernah mendapatkan nilai bagus.

3. Kadang-kadang terjadi ketidakselarasan antara keinginan atau minat seseorang dengan bakat khusus yang dimilikinya. Sering mengalami kesulitan di dalam menentukan pilihan jurusan atau jenis sekolah mana yang akan dimasuki. Hal ini dapat berakibat kepada kegagalan siswa dalam menyelesaikan studinya.

\section{Masalah yang timbul berhubungan dengan perkembangan perilaku sosial, moralitas, dan keagamaan.}

1. Keterikatan hidup dalam suatu geng (peers group) yang tidak terbimbing mudah menimbulkan juvenile delinquency (kenakalan remaja) yang berbentuk perkelahian antar kelompok, pencurian, perampokan, prostitusi, dan bentuk-bentuk perilaku anti sosial lainnya.

2. Konflik dengan orang tua dapat berakibat kaburnya anak dari rumah.

3. Melakukan perbuatan-perbuatan yang bertentangan dengan norma-norma masyarakat atau agama. Seperti mengkonsumsi narkotika.

\section{Masalah yang timbul berhubungan dengan perkembangan perilaku afektif, konatif dan kepribadian}

1. Remaja mudah sekali digerakan untuk melakukan gerakan atau kegiatan destruktif yang spontan untuk melampiaskan ketegangan instutif emosionalnya walaupun remaja sendiri tidak mengetahui maksud dan akibat dari tindakannya tersebut.

2. Ketidakmampuan menegakkan kata hati membawa akibat sulitnya mengintegrasikan dan sintesis fungsi-fungsi psiko-fisiknya. Hal ini akan berakibat terjadinya fiksasi yaitu kemandekan perkembangan dimana remaja akan hidup dalam suasana remaja yang berkepanjangan meskipun usianya sudah menginjak dewasa. ${ }^{23}$

Suatu kelompok anak berumur 11 tahun adalah betul-betul homogen, namun 6 tahun kemudian ada beberapa yang menjadi anak nakal, yang menjadi siswa teladan, beberapa menjadi ahli matematika, ada yang menjadi pemain drama, bahkan ada yang menjadi ahli mesin. Pengalaman di rumah dan di sekolah sebelum anak menjadi remaja sangat berpengaruh dalam menjadi penentu jadi apa seseorang ketika dia remaja. Hampir sebagian besar anak remaja mengalami suatu konflik emosi dan seba- 
gian kekacauan emosi tersebut dapat ditangani dengan sukses, namun untuk sebagian yang lain membuat remaja lari pada obat bius atau bahkan bunuh diri. ${ }^{24}$

Satu dari masalah yang paling serius dari remaja adalah remaja nakal atau delinquent, dan kebanyakan adalah laki-laki. Remaja nakal biasanya berprestasi rendah dan juga perilaku nakal mereka didukung oleh kelompoknya. Penyebab terjadinya juvenile delinquency pada umumnya adalah karena sebab-sebab yang kompleks yang artinya satu sebab dapat menyebabkan sebab yang lain. Jika para peneliti menyebutkan bahwa banyak kemungkinan penyebab kenakalan remaja, maka para ahli sosiologi berpendapat bahwa kenakalan remaja adalah suatu penyesuaian diri, yaitu respons yang dipelajari terhadap situasi lingkungan yang tidak sosok atau lingkungan yang memusuhinya. Hasil penelitian Robbin, berpendapat bahwa kenakalan remaja akibat adanya masalah neurobiological, sehingga menimbulkan genetik yang tidak normal. Ahli lain berpendapat kenakalan remaja merupakan produk dari konstitusi detektif mental dan emosi-emosi mental. Mental dan emosi anak remaja belum matang, masih labil, dan rusak akibat dari proses conditionering lingkungan yang buruk. ${ }^{25}$

Masalah-masalah yang timbul pada siswa penyebabnya adalah sangat komplek namun bentuk- bentuk yang dapat muncul pada siswa akibat perlakuan yang diterimanya adalah bersifat regresif dan agresif. Regresif antara lain; suka menyendiri, pemalu, penakut, mengantuk, tak mau masuk sekolah. Sedangkan yang bersifat agresif antara lain adalah; berbohong, membikin onar, memeras temannya, beringas, dan perilaku-perilaku lain yang bisa menarik perhatian orang banyak. ${ }^{26}$

Menurut penelitian Hapsari, dkk., terdapat hubungan yang signifikan antara tingginya minat siswa mengikuti ekstrakurikuler dengan rendahnya perilaku delikuen siswa. Demikian pula sebaliknya semakin rendah minat siswa untuk mengikuti kegiatan ekstrakurikuler semakin tinggi pula perilaku delikuen siswa. ${ }^{27}$

Albert K. Cohen adalah orang yang pertama kali mengungkapkan adanya istilah delinquent boys. Dalam bukunya cohen menjelaskan bahwa telah terjadi peningkatan perilaku delinquent di daerah kumuh (slum) di Amerika. Fokus perhatiannya terarah pada satu pemahaman bahwa perilaku penyimpangan dikalangan usia muda kelas bawah merupakan cerminan ketidakpuasan mereka terhadap norma-norma dan nilai kelompok kelas menengah yang mendominasi kultur Amerika. Anak kelas menengah cenderung melakukan penolakan terhadap anak kelas bawah sehingga mengakibatkan anak kelas bawah merasa tidak diakui keberadaanya di tengah masyarakat. Hal ini mendorong mereka ke arah perilaku delinquent. Lebih jauh Cohen menyatakan bahwa sub budaya delinquent pada remaja merupakan fungsi dari kondisi kehidupan berkeluarga dan sosial anak-anak yang dialami hingga saat menjelang kedewasaannya dilingkungan "ghetto" atau "kumuh". Perilaku penyimpangan bukanlah produk kelas yang inferior, melainkan fungsi dari keterbatasan-keterbatasan sosial dan ekonomi yang dialami dan diderita oleh anggota kelompok yang kurang beruntung di masyarakat. ${ }^{28}$

Berdasarkan penelitian yang dilakukan oleh Sara Z Morris dan Chris L.Gibson bahwa ternyata hukuman fisik tidak terlalu berpengaruh terhadap perilaku delinkuen anak. Hukuman fisik lebih berpengaruh kepada perubahan pada perilaku ag- 
resif anak. ${ }^{29}$ Penelitian ini memang berseberangan dengan penelitian sebelumnya yaitu yang dilakukan oleh Larzelere dan Kuhn, dimana hasil penelitiannya menunjukkan bahwa pemberian hukuman fisik dapat menjadi penyebab utama terjadinya misbehavior pada anak. Adanya perbedaan ini kemungkinan karena telah terjadi bias dan adanya faktor-faktor lain seperti keluarga, kepribadian siswa, karakter keluarga yang tidak menjadi perhatian pada penelitain Zara danChirs.

Perlu ada penelitian lebih lanjut tentang penyebab terjadinya perilaku delinkuen pada anak karena sangat berpengaruh kepada perkembangan masa remajanya. Kemungkinan pengaruh dari pola asuh orangtua, latar belakang budaya dan tentunya juga pengaruh peer group perlu diperhatikan untuk menjadi salah satu pertimbangan penyebab terjadinya perilaku delinkuen pada anak khususnya remaja.

\section{SIMPULAN}

Berdasarkan paparan singkat di atas disepakati bahwa pemberian hukuman terutama hukuman fisik selayaknya tidak diberikan kepada anak. Walaupun dalam Islam sendiri ada hadis yang membolehkan memukul anak ketika anak tidak salat, namun hukuman berupa pukulan disini ditujukan bukan untuk menyakiti anak. Sedangkan mengenai pengaruh hukuman fisik terhadap perilaku delinkuen anak atau lebih jauhnya remaja berdasarkan paparan singkat di atas dan juga diperjelas dengan beberapa pendapat dan hasil penelitian dapat disimpulkan bahwa hukuman fisik tidak terlalu mempengaruhi perilaku delinkuen pada remaja. Walaupun hukuman fisik itu diterima anak sejak anak kecil.

Perlu ada penelitian lebih jauh mengenai persoalan ini, dimana bisa ditempuh dengan cara kuantitatif yang dapat menjelaskan tentang pengaruh atau dampak yang ditimbulkan dari pemberian hukuman fisik terhadap anak dan penyebab perilaku delinkuen pada remaja. Berikut ada beberapa solusi untuk menghindari pemberian hukuman fisik kepada siswa atau anak. Solusi sistematis yang dapat diterapkan pada siswa daripada menggunakan hukuman fisik adalah:

1. Memanggil dan menerima siswa yang bermasalah dengan penuh kasih sayang

2. Melakukan wawancara dialogis, diusahakan untuk dapat mengungkap masalah utama yang menjadi penyebab munculnya perilaku.

3. Memahami keberadaan anak dengan sedalam-dalamnya

4. Menunjukkan kepada anak cara penyelesaian masalah yang tepat untuk kemudian dapat direnungkan oleh anak sehingga anak mau mengerjakannya

5. Menemukan segi-segi kelebihan pada anak agar kelebihan itu dapat diaktualisasikan oleh guru dalam mengatasi kekurangan siswa

6. Menanamkan nilai-nilai agama yang baik dan benar.

Solusi sistematis ini tentunya tidak hanya melibatkan pihak sekolah tetapi tentunya juga perlu adanya dukungan dari pihak orangtua. 


\section{CATATAN AKHIR}

1. Marno dan M. Idris, Strategi dan Metode Pengajaran, Ar-Ruzz Media: Jogjakarata, 2009, h. 133.

2. Sri Esti Wuryani Djiwandono, Psikologi Pendidikan, Grasindo, Jakarata, 2006, h. 330.

3. Abu Ahmadi dan Nur Uhbiyati, Ilmu Pendidikan, Rineka Cipta, Jakarta, 2003, h.. 150-151

4. Ibid, h. 157

5. Sara Z. Morris and Chris L. Gibson, “Corporal Punishment's Inffluence on Children's Aggressive and Delinquent Behavior", Journal of Criminal Justice and Behavior 2011 38:818. h. 819

6. W. James Popham dan Eva L.Baker, Teknik Mengajar Secara Sistematis, diterjemahkan oleh Amirul Hadi dkk, Rineka Cipta, 2003, h. 110-111.

7. Ibid., h. 111.

8. Kompas, Dari KBK sampai MBS (esai-esai pendidikan J. Drost, SJ), Kompas, 2006, h. 30.

9. Ibid, h. 31

10. Kenneth A.Strike dan Jonas F.Soltis, Etika Profesi Kependidikan, Terjemahan F.SInaradi, Universitas Sanata Dharma, 2007, h. 157.

11. Arini el-Ghaniy, Saat Anak Harus Dihukum!, Power books publishing, Jogjakarta, 2009, h. 52-57.

12. Koesworo, Agresi Manusia, Eresco, Bandung 1988, h.67.

13. Sunarto dan B.Agung Hartono, Perkembangan Peserta Didik, Rineka Clpta, Jakarta, 2008, h. 35.

14. Ibid., h. 39 .

15. M. Dalyono, Psikologi Pendidikan, Rineka Cipta, Jakarta, 2009, h. 101-102.

16. Djaali,H., Psikologi Pendidikan, Buah Aksara, Jakarta, 2008, h. 39.

17. Ibid., h. 49.

18. Hurlock. E.B., Psikologi Perkembangan: Suatu Pendekatan Sepanjang Rentang Kehidupan, Alih Bahasa Dra. Istiwidayanti dan Drs. Soedjarwo, M.Sc., Erlangga, Jakarata, 1999, h. 9.

19. Ibid., h. 209.

20. Fuhrmann, B.S, Adolescence, Adolescent, Scott, Foresman/ Liitle, Brown Higher Education, Illinois, 1990, h. 334.

21. Syaikh M. Jamaluddin Mahfuzh, Psikologi Anak dan Remaja Muslim, terjemahan Abd. Rosyad Shiddiq dan Ahmad Vathir Zaman, Pustaka Al-Kautsar, 2001, h. 76-77.

22. Abin Syamsuddin Makmun, Psikologi Pendidikan (Perangkat Sistem Pengajaran Modul), Rosda Karya, Bandung, 2004, h. 135.

23. Ibid, h. 136-137.

24. Sri Esti Wuryani, op. cit., h. 112.

25. Ibid., h. 112-113.

26. M. Dalyono, op. cit., h. 265-266.

27. Utami Retno Hapsari., dkk, Hubungan Antara MInat Mengikuti Kegiatan Ekstrakurikuler Dengan Intensi Delinkuensi Pada Siswa Sekolah Menengah Kejuruan (SMK) di Kota Semarang, Jurnal Fakultas Psikologi Undip, Semarang, 2010, h. 19.

28. Paulus Hadisuprapto, “Teori Perilaku Delinkuen (Tinjauan Teoritis) Teori Subkulture Delinkuen, Teori Netralisasi, Teori Kontrol Sosial", Makalah pada Penataran Nasional Hukum Pidana dan Kriminologi, Bandung-Ambarawa, 14 s/d 30 November 1994, h. 8-9.

29. Sara Z. Morris and Chris L. Gibson, op. cit., h. 835. 


\section{DAFTAR PUSTAKA}

Ahmadi, Abu dan Nur Uhbiyati. Ilmu Pendidikan. Jakarta: Rineka Cipta, 2003.

Dalyono, M. Psikologi Pendidikan. Jakarta: Rineka Cipta, 2009.

Djaali, H. Psikologi Pendidika. Jakarta: Buah Aksara, 2008.

Djiwandono, Sri Esti Wuryani. Psikologi Pendidikan. Jakarta: Grassindo, 2006.

Fuhrmann, B.S. Adolescence, Adolescent. Illinois: Scott, Foresman/Little, Brown Higher Education, 1990.

el-Ghaniy, Arini. Saat Anak Harus Dihukum! Jogjakarta: Power Books Publishing, 2009.

Hadisuprapto, Paulus. "Teori Perilaku Delinkuen (Tinjauan Teoritis) Teori Subkulture Delinkuen, Teori Netralisasi, Teori Kontrol Sosial." Makalah pada Penataran Nasional Hukum Pidana dan Kriminologi. Bandung-Ambarawa, 14 s/d 30 November 1994.

Hapsari, Utami Retno, dkk. "Hubungan Antara MInat Mengikuti Kegiatan Ekstrakurikuler dengan Intensi Delinkuensi pada Siswa Sekolah Menengah Kejuruan (SMK) di Kota Semarang." Jurnal. Fakultas Psikologi Undip. Semarang: Tidak Diterbitkan, 2010.

Hurlock, E.B. Psikologi Perkembangan. Suatu Pendekatan Sepanjang Rentang Kehidupan, Alih Bahasa Dra. Istiwidayanti dan Drs. Soedjarwo, M.Sc. Jakarta: Erlangga, 1999.

Koesworo. Agresi Manusia. Bandung: Eresco, 1988.

Kompas. Dari KBK sampai MBS (Esai-esai Pendidikan J. Drost, SJ). Jakarta: Penerbit Buku Kompas, 2006.

Mahfuzh, Syaikh M. Jamaluddin. Psikologi Anak dan Remaja Muslim. Diterjemahkan Abd. Rosyad Shiddiq dan Ahmad Vathir Zaman, Jakarta: Pustaka Al-Kautsar, 2001.

Makmun, Abin Syamsuddin. Psikologi Pendidikan (Perangkat Sistem Pengajaran Modul). Bandung: Rosda Karya, 2004.

Marno dan M. Idris. Strategi dan Metode Pengajaran. Jogjakarata: Ar-Ruzz Media, 2009.

Morris, Sara Z. and Chris L.Gibson, “Corporal Punishment's Inffluence on Children's Aggressive and Delinquent Behavior." Journal of Criminal Justice and Behavior, 2011, 38: 818, 2011.

Popham, W. James dan Eva L. Baker. Teknik Mengajar Secara Sistematis. Diterjemahkan oleh Amirul Hadi dkk. Jakarta: Rineka Cipta, 2003.

Strike, Kenneth A. dan Jonas F. Soltis. Etika Profesi Kependidikan. Diterjemahkan F. Sinaradi. Jogjakarata: Universitas Sanata Dharma, 2007.

Sunarto dan B. Agung Hartono. Perkembangan Peserta Didik. Jakarta: Rineka Cipta, 2008. 